\title{
Morphological identification of Ilyonectria liriodendri and its interaction with plant growth-promoting bacteria in grapevine rootstocks
}

\author{
Liliane Martins de Brito ${ }^{1}$, Flávio Zanette ${ }^{2}$, Luiz Antonio Biasi², \\ Murilo Dalla Costa ${ }^{3}$, João Frederico Mangrich dos Passos ${ }^{4}$
}

\begin{abstract}
In order to analyze the pathogenicity and antagonism between grapevine rootstocks and soil microorganisms, plant growth-promoting bacteria with antibiotic effect were selected from the phytopathogen Ilyonectria liriodendri, 2T-VSC-101 isolated monosporic, in in vitro antibiosis tests. The bacterial access that produced the largest zone of inhibition was used in the seedling biotization of the grapevine rootstocks P1103, IBBT481 and VR039-16. From the interaction between isolates of plant growth-promoting bacteria and Ilyonectria liriodendri isolate resulted in three bacterial isolates with control of the mycelial growth of the phytopathogen, all of the Burkholderia gender. However, the highest control bacterium, Burkholderia catarinensis sp. nov. isolated POA 89, was found to be detrimental to the in vitro development of rootstocks, causing them to die. The cultivation through culture medium modified with sand was adequate for the in vitro growth of the rootstocks and appropriate for the observation of the black foot disease's characteristic symptoms. From the ex vitro cultures with the IBBT481 rootstock and the microorganisms, there were results in favorable effects to the plants inoculated with the bacterium in combination with the phytopathogen. It also demonstrated the difficulty of acclimatization and growth of this access in a greenhouse.

Index terms: Micropropagation, acclimatization, Burkholderia catarinensis sp. nov., Ilyonectria liriodendri.

\section{Identificação morfológica de Ilyonectria liriodendri e sua interação com bactérias promotoras de crescimento de plantas em porta enxertos de videira}

Corresponding author: liliane.brito@ifc.edu.br

Received: October 29, 2018 Accepted: June 18, 2019

Copyright: All the contents of this journal, except where otherwise noted, is licensed under a Creative Commons Attribution License.

\section{(cc) $\mathbf{E Y}$}

\begin{abstract}
Resumo - Com a finalidade de analisar a patogenicidade e o antagonismo entre porta-enxertos de videiras e microorganismos de solo, procedeu-se à seleção de bactérias promotoras de crescimento de plantas com efeito antibiótico ao fitopatógeno Ilyonectria liriodendri, isolado monospórico 2T-VSC-101, em testes de antibiose in vitro. $\mathrm{O}$ acesso bacteriano que produziu a maior zona de inibição foi utilizado na biotização de mudas dos porta-enxertos de videira P1103, IBBT481 e VR039-16. Da interação entre isolados de bactérias promotoras de crescimento de plantas e o fungo causador da doença-pé-preto-da-videira, resultaram, três isolados bacterianos com controle sobre o crescimento micelial do fitopatógeno, todos do gênero Burkholderia sp. Entretanto, a bactéria de maior controle, Burkholderia catarinensis sp. nov. isolado POA 89, mostrou-se prejudicial ao desenvolvimento in vitro dos porta-enxertos, causando-lhes a morte. $\mathrm{O}$ cultivo com meio de cultura modificado com pedrisco mostrou-se adequado ao crescimento in vitro dos porta-enxertos e apropriado à observação dos sintomas característicos da doença pé-preto. Das culturas ex vitro com o porta-enxerto IBBT481 e os microorganismos, resultaram efeitos favoráveis às plantas inoculadas com a bactéria em combinação com o fitopatógeno. Também demonstrou a dificuldade de aclimatização e de crescimento desse acesso em casa de vegetação.
\end{abstract}

Termos para indexação: Micropropagação, aclimatização, Burkholderia catarinensis sp. nov., Ilyonectria liriodendri.

\footnotetext{
${ }^{1}$ Eng. Agr., Prof. EBTT, Inst. Fed. de Educação Ciência e Tecnologia Catarinense, Videira-SC, Brasil. E-mail:liliane.brito@ifc.edu.br ${ }^{\text {(ORCID: }}$ 0000-0002-6192-291X),

${ }^{2}$ Eng. Agr., Prof. Titular do Departamento de Fitotecnia e Fitossanitarismo, Universidade Federal do Paraná, Curitiba-PR, Brasil. E-mails: flazan@ufpr.br (ORCID: 0000-0001-5917-6711); biasi@ufpr.br (ORCID: 0000-0002-3479-8925)

${ }^{3}$ Eng. Agr., Doutor, Laboratório de Biotecnologia, Empresa de Pesquisa Agropecuária e Extensão Rural de Santa Catarina S. A. - EPAGRI, Lages-SC, Brasil. E-mail: murilode@epagri.sc.gov.br (ORCID: 0000-0001-7422-1883)

${ }^{4}$ Eng. Agr., Doutor, Laboratório de Biotecnologia, Empresa de Pesquisa Agropecuária e Extensão Rural de Santa Catarina S. A. - EPAGRI, Lages-SC, Brasil. E-mail: joaopassos@epagri.sc.gov.br(ORCID: 0000-0002-5831-5131)
} 


\section{Introduction}

The incidence of trunk fungal diseases has increased significantly in different areas of grapevine production worldwide, particularly in nurseries and new vineyards (ALANIZ et al., 2007; AGUSTÍBRISACH and ARMENGOL, 2013). This fact triggered a renewed interest in research on resistant rootstocks, on these diseases and their causative agents. Among the phytopathologies, there is the black foot disease of the vine, caused by fungi related to anamorphs of the Cylindrocarpon type, such as the Ilyonectria gender (CHAVERRI et al., 2011; CABRAL et al. 2012;AGUSTÍBRISACH et al., 2014). Among Ilyonectria species, I. liriodendri (Halleen, Rego \& Crous) Chaverri \& Salgado (RUSSI et al., 2010) is one of the main threats to vines, observed in vineyards in France, Portugal, South Africa (REGO et al., 2000; HALLEEN et al., 2006), Spain (ALANIZ et al., 2009), Iran (MOHAMMADI et al., 2009) and New Zealand (PATROSE et al., 2014). This species has also been described as a pathogen that causes black foot disease of the vine in Brazil by Russi et al. (2010). Plants affected by the plant pathogen show necrotic lesions in the roots, with a reduction in root biomass, besides other symptoms that include vigor reduction, internodes shortening, sparse foliage and small leaves with chlorosis and necrosis between the veins, often leading to the plants to die (ALANIZ et al., 2007; PETIT et al., 2011; AGUSTÍ-BRISACH and ARMENGOL, 2013). The characteristic black coloration of the affected plants is due to the necrosis of the wood tissue that develops from the base of the rootstock (FONTAINE et al., 2016). Currently, many wine-growing regions have restricted the use of pesticides in vines, not only because of detectable chemical residues, but also because they cause the emergence and establishment of strains of resistant pathogenic microorganisms (ALANIZ et al., 2011). Staley et al. (2014) describe that the wide-scale application of agrochemicals has become increasingly scrutinized in recent years for possible contributions to human health risks, including potentially carcinogenic effects and prolonging the survival of agriculturally associated zoonotic pathogens. As a result, legislation in most countries is becoming more severe, leading to an increasing need for alternative techniques to chemical management (SENGUPTA and GUNRI, 2015; GRIMALT and DEHOUCK, 2016) and it will depend on suitable varieties that present qualitative characteristics in the production of grape and wine. Therefore, cultivars considered traditional or recently introduced, such as Paulsen 1103 ( $V$. berlandieri $\mathrm{x} V$. rupestris $)$ and VR039-16 $(V$. vinifera $\times V$. rotundifolia $)$, besides others in experimental phase, such as the rootstock IBBT481 ( . labrusca 'Isabel' x V. rotundifolia 'Bontiful') (REINHART, 2013), have present potential characteristics for viticulture, especially in the control of the root system diseases, such as the phytopathogen Fusarium oxysporum $\mathrm{f}$ sp. herbemonitis (RANA et al., 2017). One strategy to obtain those seedlings is the tissue cultivation in vitro or micropropagation (BETTONI et al., 2015). Another possibility is the use of microorganisms beneficial to the crop. Plant growthpromoting bacteria (PGPB) may be an alternative, since they are able to colonize, survive and multiply in microhabitats associated with the root surface (AHMAD et al., 2008; SANTOYO et al., 2016). These interactions promote the vegetative development of the grapevines, either directly, producing plant hormones, or indirectly, altering the microbial balance in the rhizosphere and disfavoring phytopathogens by antibiosis or induction of systemic plant resistance (COMPANT et al., 2010; GLICK, 2012; MONCADA et al., 2015). The beneficial effects can be observed in plants propagated in vitro and ex vitro mainly by increasing leaf area, plant height, stem diameter, number of leaves and dry biomass. They are also useful in reducing the time of acclimatization, the greater survival of seedlings, the control of diseases and the increase of productivity. They can be used in micropropagated plants, incorporated into the culture medium or planting substrate, in treatments of cuttings and roots (MARIANO et al., 2004; GLICK, 2012). Studies on the effects of simple and combined inoculation between microorganisms on seedling production are being carried out, mainly those of agronomic interest (ADESEMOYE and KLOEPPER, 2009). Micropropagation methods in pathogenicity and bioassay tests become necessary and require studies (NOWAK, 1998; GOSAL et al., 2010; ORLIKOWSKA et al., 2017), since these techniques must, on the one hand, favor the proper vegetative development of the plants and, on the other hand, externalize the interactions between microorganisms and tested genotypes. In order to evaluate the development of micropropagated P1103, VR039-16 and IBBT481 rootstocks in in vitro growth environments, for further pathogenicity and antagonism tests, simple and combined inoculation experiments were performed with plant growth promoting bacteria and the phytopathogen causing the black foot disease of the grapevine during the micropropagation and acclimatization of those plants.

\section{Material and methods}

\section{In vitro antibiosis tests}

The isolates of the phytopathogen were recovered from trunk tissue fragments and roots of three years old grapevine (rootstock cv. VR043-43), which presented characteristic lesions of the disease. Segments, after asepsis, were transferred to PDA medium (Potato, 
Dextrose, Agar) with $1.000 \mathrm{mg} \mathrm{L}^{-1}$ rifampicin and incubated at $25 \pm 1{ }^{\circ} \mathrm{C}$. After 10 days, when the structures were observed with conidia, a suspension was obtained by scraping the surface of the mycelium. One drop of this portion was streaked on agar/water medium containing plate to dilute the conidia and obtain the isolated monosporic. After 48 hours, the germinated spores were removed from the plate with the aid of a stylet, under a microscope and in a laminar flow chamber, peeled into the PDA medium and incubated at $25 \pm 1{ }^{\circ} \mathrm{C}$ for 20 days until the mycelial growth reaches the edges of the Petri dish (GARRIDO et al., 2004). Subsequently, the isolates of the fungus were characterized according to: the colony (color, appearance, diameter and reverse in PDA); the conidiophores (characterization); conidia (type, size, presence of scar, septation, coloration and shape); chlamydospores (presence, color and diameter); and sporulation. The identification was carried out with the aid of the identification keys for the species of Brayford (1987), Samuels and Brayford (1990), Brayford (1993) and Alaniz et al. (2007). In the antibiosis experiments the isolated monosporic 2T-VSC-101 identified as Ilyonectria liriodendri was used. Twelve isolates of PGPB, selected according to availability in the germplasm bank of the Biotechnology Laboratory of the Company of Agricultural Research and Rural Extension of Santa Catarina (EPAGRI) Lages - SC, were inoculated in King-B liquid medium (KING and KING, 1954), using $100 \mu \mathrm{L}$ suspension of the bacteria per test tube containing $10 \mathrm{~mL}$ of the liquid medium. Four test tubes, at $28 \pm 1{ }^{\circ} \mathrm{C}$, per bacterium were used and agitated to provide aeration and environment suitable for growth until reaching $150 \times 10^{6}$ bacterial cells per $\mathrm{mL}$ of medium by the nephelometric scale of MC Farland NEFELOBAC (LENNETTE et al., 1985). The bacterial isolates were tested in PDA medium, placing a $0.5 \mathrm{~cm}$ agar disc with abundant growth of the pathogenic fungus in the center of the plaque, and at the extremities, four bacterial streaks. After 10 days of incubation, the reduction of mycelial growth was measured. The experiment was carried out in a completely randomized design with six replications; phytopathogenic: Ilyonectria liriodendri; antagonists: Rohnella sp. (isolated POA 9), Burkholderia sp. (isolated POA 75, 89, 187, 208, 195, 245 e 253), Pseudomonas sp. ( isolated POA 108), Leclercia sp. ( isolated POA 209 e 210) e Ewingela sp. ( isolated POA 242). Subsequently, a triplicate was performed with the bacteria that showed inhibitory effect. The bacterial isolate that produced the largest zone of inhibition was stored in liquid medium King-B at $-5{ }^{\circ} \mathrm{C}$. The mean radius $(\mathrm{MR}, \mathrm{cm})$ of the pathogen colonies paired with the endophytic isolate and the relative inhibition (RI, \%) were measured and calculated (SHIOMI et al., 2008). The data were submitted to analysis of variance by the $\mathrm{F}$ test, at the $5 \%$ probability level, using the program
Assistat Software version 7.7 (SILVA and AZEVEDO, 2016); when necessary, the Box-Cox transformation was applied to the variables (OSBORNE, 2010). The means were compared by the Tukey test, at $5 \%$ probability.

In vitro antagonism and pathogenicity tests

Nodal segments of the rootstocks P1103 ( $V$. berlandieri $\times$ V. rupestris), VR039-16 (V. rotundifolia $\mathrm{x} V$. vinifera) and IBBT481 ( $V$. labrusca 'Isabel' $\mathrm{x} V$. rotundifolia 'Bontiful') were submitted to disinfestation with ethanol $(70 \%)$ and sodium hypochlorite $(1.5 \%)$ (BETTONI et al., 2015), subsequently established and multiplied, in Murashige and Skoog culture medium - MS (MURASHIGE and SKOOG, 1962), with half the concentration of salts, free of growth regulators, solidified with $7 \mathrm{~g} \mathrm{~L}^{-1}$ de agar $\left(\right.$ Merck $\left.^{\circledR}\right)$; the $\mathrm{pH}$ adjusted to 5.8 before autoclaving at $121{ }^{\circ} \mathrm{C}$, for 20 minutes. The explants were maintained in growth chambers for 40 days and after this period were sub cultivated in 240 $\mathrm{mL}$ flasks with MS culture medium with half the salt concentration, solidified with agar (MSA/2) or with sand $(\mathrm{MSS} / 2)>1.4 \mathrm{~mm}$, autoclaved at $120^{\circ} \mathrm{C}$ for 60 minutes. When they reached $4 \mathrm{~cm}$ and 4 leaves, the grapevine rootstocks plants were inoculated with the isolate of PGPB Burkholderia catarinensis sp. nov. isolated POA 89 (BACH et al., 2017), isolated that presented greater antibiosis action in vitro. Two milliliters of the suspension were used with approximately $150 \times 10^{6}$ of the bacterium per $\mathrm{mL}$ of the liquid medium King-B, directly in the growth medium (LENNETTE et al., 1985). The other plants constituted the control treatment and received 2 $\mathrm{mL}$ of the solution without the bacterium, to simulate the equal growth conditions. The pathogen was inserted after 7 days of inoculation of the bacterium, placing a $0.5 \mathrm{~cm}$ agar disc with abundant growth of the fungus at the base of the seedling. The biotization of the growth medium with the bacteria and the inoculation of the pathogenic fungus were made in laminar flow chamber. The plants remained at $25{ }^{\circ} \mathrm{C}$ with photoperiod of $16 \mathrm{~h}$. After 30 days, the presence or absence of symptoms of black foot disease and damage to the seedlings were evaluated. The lesions in the roots of the seedlings were evaluated according to the percentage (\%) of darkened roots visible in the growth medium in vitro. The foliar damages were measured according to the percentage $(\%)$ of the changes in leaf color and necrosis, with the aid of the AutoCAD 2014 program (MORAES et al., 2013). The experiment was carried out in a completely randomized design, with 10 replicates and one plant per experimental unit. The data were submitted to analysis of variance and the means were compared by the F test, at the 5\% probability level, using the software Assistat Software version 7.7 (SILVA and AZEVEDO, 2016); when necessary, the Box-Cox transformation was applied to the variables (OSBORNE, 2010). The means were compared by the Tukey test, at 
$5 \%$ probability.

\section{Tests of antagonism and pathogenicity ex vitro}

In this study, seedlings from the in vitro propagation of the IBBT481 rootstock were used. Inoculations with the PGPB were performed at the beginning of acclimatization, at which time the seedlings were transplanted to trays with commercial substrates Tecnomax $^{\circledR}$ and and washed sand, in the ratio of 2 volumes of the substrate to 1 of washed sand $(2: 1 / \mathrm{v}: \mathrm{v})$, plus $2 \mathrm{~mL}$ of the solution of the liquid medium King-B (KING and KING, 1954) with the bacterium Burkholderia catarinensis sp. nov. isolated POA 89. The other plants constituted the control treatment and received, next to the substrate, $2 \mathrm{~mL}$ of the solution of the liquid medium King-B, to simulate the equal growth conditions. The trays were protected with plastic against moisture loss and transferred to the plant growth room, at $25{ }^{\circ} \mathrm{C}$. After 38 days, with the progressive opening of the tray lining, the seedlings were transplanted to 550 $\mathrm{mL}$ pots with the same commercial substrate and washed sand mixture, at which time the pathogen Ilyonectria liriodendri, isolated monosporic 2T-VSC-101, was inoculated with suspension corrected for $1 \times 10^{6}$ spores $\mathrm{cm}^{-3}$ (ALANIZ et al., 2011). For this procedure, the roots of the seedlings were pruned, washed in running water and placed in the spore solution with macro and microconidia obtained from the scraping of the mycelium of PDA cultures, for an hour. The control treatments were immersed in distilled water for the same period. After inoculation, the seedlings were watered daily with $20 \mathrm{~mL}$ of distilled water and, ten days after the first transplant, were irrigated with $10 \mathrm{~mL}$ of Long-Ashton nutrient solution (RESH, 1997). After 90 days of ex vitro growth, the plants were analyzed according to the interaction between the rootstock interaction, between inoculation of PGPB and/or pathogenic fungus, for the vegetative growth variables: height of the main stem $(\mathrm{cm})$ and total dry biomass $(\mathrm{g})$. The treatments were arranged in a completely randomized experimental design, with 10 replicates and one plant per experimental unit. The data were submitted to analysis of variance and the means were compared by the $\mathrm{F}$ test, at the $5 \%$ probability level, using the software Assistat Software version 7.7 (SILVA and AZEVEDO, 2016); when necessary, the Box-Cox transformation was applied to the variables (OSBORNE, 2010). The means were compared by the Tukey test, at $5 \%$ probability.

\section{Results and Discussion}

Four isolated monosporic were obtained from the recovery of fungus causing the black foot on grapevine rootstock 043-43 with lesions characteristic of the disease, identified by 1D-VSC-005, 2T-VSC-101, 3C-VSC-194 and 4I-VSC-314. Of these, the isolated monosporic 2T-VSC-101, used in the studies of antibiosis and antagonism, presented morphological and cultural patterns characteristic of the anamorph species Ilyonectria liriodendri. The colony presented aerial mycelium, flaky to the mat, with coloration that varied from white to yellow or light brown after 20 days of incubation under fluorescent light at $25{ }^{\circ} \mathrm{C}$, reaching approximately $57.8 \mathrm{~mm}$ in diameter. The margins of the colonies were whole, slightly lobulated (FIGURE 1C). The daily growth rate $(\mathrm{mm})$ at $5{ }^{\circ} \mathrm{C}$ of $(0.23) 0.40(0.49)$ and at $10{ }^{\circ} \mathrm{C}$ of $(0.50) 0.75(0.87)$. The reverse of the plaques was ocher to orange in PDA (FIGURE 1D). The fungus culture formed isolated or united conidiophores in the form of sporodochia. In the end, it was possible to observe macro or microconidia. The rarer microconidia were hyaline, elliptic to oval, measuring (7.3) 9.0 (13.1) $\mu \mathrm{m}$ in length and (1.4) 2.5 (5.1) $\mu \mathrm{m}$ wide, with a lateral thread. The macroconidia had one to three septa and were more abundant (FIGURE 1A). They were hyaline, cylindrical to slightly curved with rounded ends, with a slight narrowing at the base, with basal wire. The macroconidia with a septum presented a length of (10.0) 15.8 (18.9) $\mu \mathrm{m}$ and a width of (2.0) 3.4 (4.8) $\mu \mathrm{m}$; with two septa presented a length of (12.0) 23.1 (29.2) $\mu \mathrm{m}$ and a width of (3.3) $5.0(6.8) \mu \mathrm{m}$; and with three septa presented a length of (22.4) 30.9 (33.5) $\mu \mathrm{m}$ and a width of (3.8) $5.4(7.0) \mu \mathrm{m}$. The sporulation of the isolate showed 11.3 a $5.4 \times 10^{6}$ conidia per $\mathrm{mL}$. There was a discrete presence of resistance spores or chlamydospores. These were medium brown, formed singly or in short chains, ellipsoids, measuring $8.5-20 \times 9.0-16.5 \mu \mathrm{m}$. Chlamydospores were intercalary or terminal in the mycelium, singly or occasionally in chains. The growth rates of the 2T-VSC-101 isolate at 5 and $10{ }^{\circ} \mathrm{C}$ and its sporulation were very similar to the means indicated by Alaniz et al. (2007) and Mohammadi et al. (2009). These authors reported that these characters are among the most important for the phenotypic differentiation between species, previously accepted as the main causal agents of the black foot (CABRAL et al., 2012), I. liriodendri and I. macrodidyma. However, the presence of resistance spores was lower than those obtained by Agustí-Brisach and Armengol (2013) under the conditions of phytopathogen cultivation. In vitro antibiosis tests among the twelve isolates of plant growth-promoting bacteria (PGPB) and the fungus causing the black foot disease of the vine resulted in three bacterial isolates with control over the mycelial 
growth of the species Ilyonectria liriodendri isolated monosporic 2T-VSC-101 (ILY), all from of the genre Burkholderia sp. The POA isolates 75,89 and 245 reduced mycelial growth around $2.0 \mathrm{~cm}$ and obtained significant inhibitory effects in relation to the phytopathogen, however the bacterium Burkholderia catarinensis sp. nov. isolated POA 89 (BACH et al., 2017) exercised greater control (TABLE 1). This bacterium originates from grasslands soils from Lages (SC) and is characterized by producing siderophore, by depriving organisms of the absorption of iron, and for producing the auxin indoleacetic acid (AIA) and for not producing phosphate (PASSOS et al., 2014) as well as for having an inhibitory control on the mean mycelial growth of the phytopathogen of $42.69 \%$ (FIGURE 1D, TABLE 1). Similar inhibitory effects were obtained by Shiomi et al. (2008), who observed a strong antagonistic action in vitro of Bacillus subtilis and B. lentimorbus against the fungus Rhizoctonia solani. The authors reported that both Bacillus isolates reduced the mean mycelial growth of $6.33 \mathrm{~cm}$ from the control treatment to $3.23 \mathrm{~cm}$, a control of $48.9 \%$ on the pathogen causing numerous plant diseases. The effect of in vitro inoculation with the isolated monosporic 2T-VSC-101 of the pathogenic fungus in micropropagated plants of the grapevine rootstocks P1103, VR039-16 and IBBT481 was negative on the health of the plants in the different treatments. In the treatments with Ilyonectria liriodendri was possible to observe leaf and rootstock damage after 30 days of in vitro growth. These seedlings presented similar reactions to the insertion of the microorganism $(-B A C+$ ILY) in growth environments solidified with agar (MSA/2) or sand (MSS/2) on changes in color and necrosis on leaves, but at different intensity and damage to root system (FIGURE 2). The foliar damages ranged from $10.90 \%$ to $12.64 \%$ between rootstocks and micropropagation environments when inoculated with the phytopathogen, presenting no significant differences. However, root damage was greater in the vines of P1103, VR039-16 and IBBT481 which were grown in modified growth medium with sand (MSS/2). In these growing environments, the rootstocks showed average damages of $80.09 \%$. This result was 2.6 times higher in the roots than in plants growing in medium solidified with agar (MSA/2), whose mean damage was reduced to around $29.90 \%$ (FIGURE 2). This fact may be related to the trophic relationships of the fungi in their environment of existence. In a nutrient-rich environment, the fungus may become saprophytic, preferring to feed on the growth medium instead of infecting the host plant (THOMMA, 2003; BERG and SMALLA, 2009). On the contrary, the in vitro growth environment modified with sand, more aerated and/or with less access to the nutrients, facilitates the infection of the seedlings by the phytopathogen and, later, the development of the characteristic symptoms of the disease, in which is verified the darkening of the roots, which gives it the name black foot (FIGURE 3 A2, B2). On the other hand, the use of the Burkholderia catarinensis sp. nov. isolated POA 89 by combination with grapevine rootstocks and phytopathogen Ilyonectria liriodendri isolated 2T-VSC-101 (+BAC-ILY; +BAC+ILY), caused a rapid darkening of leaf blade and root system, leaf fall and later death of micropropagated plants after 30 days of inoculation (FIGURE 3C). The leaf and root system damages were higher than the non-inoculated treatments (-BAC-ILY; -BAC+ILY) in the different in vitro growth environments, masking the effects of the pathogenic fungus and antibiosis or indicating that, in the study conditions, it was inhibitory or pathogenic to plants (FIGURE 2). This result can be related to many factors such as competition, synergism or phytotoxic bacterial exudates for growing plants (BAIS et al., 2006; GAIERO et al., 2013), circumstance that still needs to be investigated. Contrary to the tests of antagonism and pathogenicity in vitro, the ex vitro inoculation of the IBBT481 grapevine rootstock with the isolated POA 89 did not result in vegetative damage or plant deaths. The results showed a favorable effect on the plants inoculated with the bacterium in combination with the phytopathogen Ilyonectria liriodendri, isolated monosporic 2T-VSC-101 (+BAC+ILY). These grapevines had a height of $6.67 \mathrm{~cm}$ and $0.13 \mathrm{~g}$ of total dry biomass, superior results compared to non-biotiplated plants or inoculated with one of the microorganisms alone (TABLE 2). Inoculation with the phytopathogen potentiated the effect of the bacterium on synergistic effect (LAMICHHANE and VENTURI, 2015). However, the failure to observe the characteristic symptoms of black foot disease in the treatments with the phytopathogen (-BAC+ILY) may be related to the insufficient period of 90 days of incubation and/or the absence of stress to trigger the symptoms. Alaniz et al. (2009) and Pathrose et al. (2014) observed that in many cases the presence of the black foot cause on rootstocks is not expressed by external symptoms. They state that the asymptomatic presence of these pathogens can be explained by the fact that these fungi are able to survive as saprophytes, endophytes or as latent pathogens until the plant is exposed to a stress condition. The absence of this circumstance can be observed by the discrete presence of resistance spores, or chlamydospores, produced by the phytopathogen during the characterization of the isolated monosporic 2T-VSC-101. These more resistant structures indicate adverse conditions because they are produced in aggressive environments, such as low temperatures, unfavorable $\mathrm{pH}$ and nutrient deficiency (SUN et al., 2019). Moreover, Cabral et al. (2012) detected variation in the virulence among isolates of pathogenic fungi related to the black foot disease of the vine, reporting that the phytopathogen 
Ilyonectria liriodendri was less virulent among the species studied. The results may also be associated to IBBT481 plants, which presented difficulties in acclimatization and ex vitro establishment. In their studies, REINHART (2013) demonstrated that the hybrid IBBT481 showed the lowest percentage of survival $(42.11 \%)$ and explants with shoots $(60 \%)$, values considered low compared to the other hybrids tested. Regarding to the studies, only the treatment with Ilyonectria liriodendri without the growth promoting bacterium (-BAC+ILY), inoculated in micropropagated plants of the grapevine rootstocks P1103, VR039-16 and IBBT481 in growth medium modified with sand (MSS/2), allowed the recovery of the isolated monosporic inoculated of the phytopathogen, required by the Koch postulate. Nevertheless, although preliminary, in vitro studies indicate the possibility of interaction analysis in less time (30 days), the same for evaluation in an ex vitro environment (greater than 90 days), allowing to observe its use in the disease observation in different pathogenhost systems, in subsequent testing for the treatment of plants in a greenhouse and in the field.

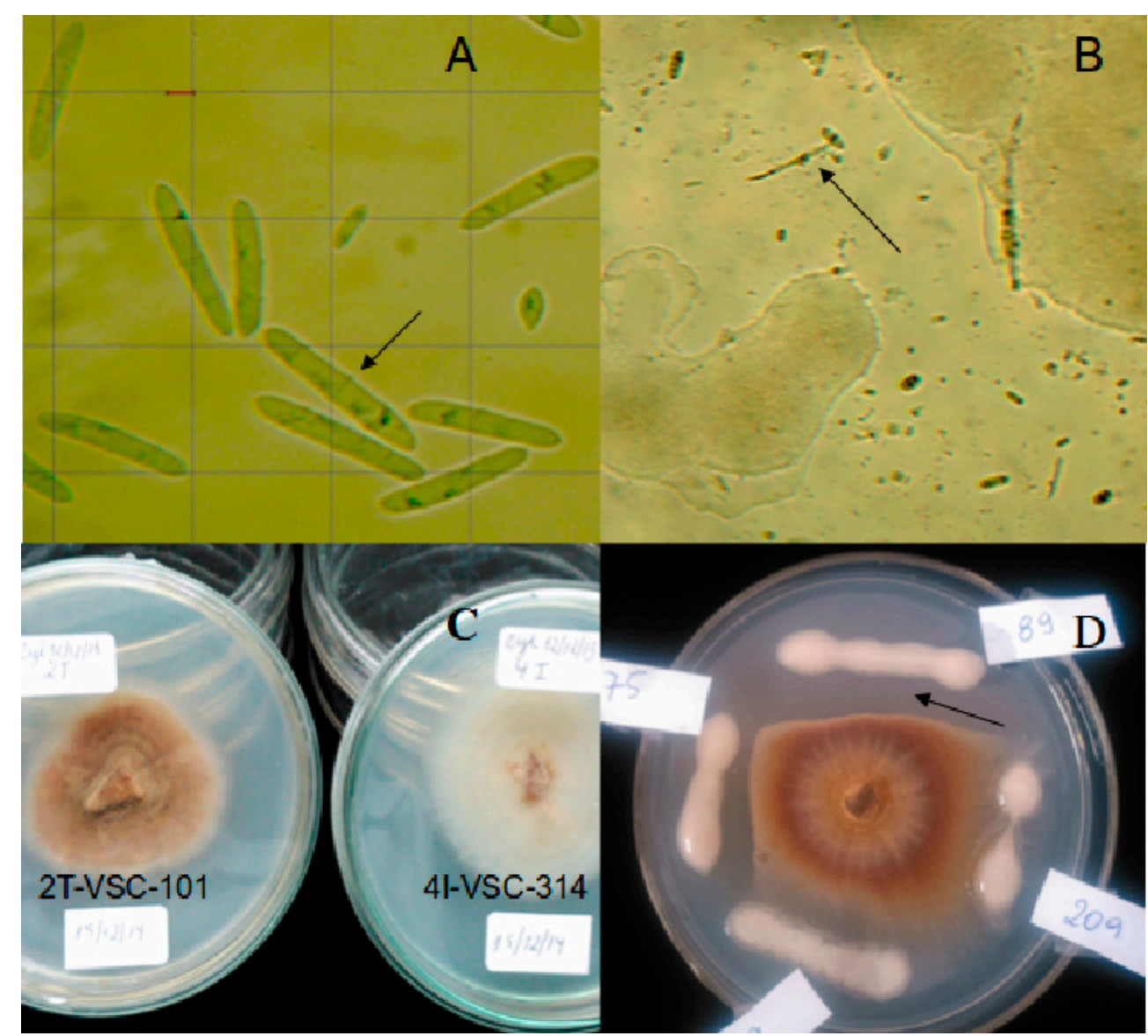

Figure 1- (A) Microconidia and septate macroconidia of the fungus Ilyonectria liriodendri isolated monosporic 2T-VSC-101 (5 $\mu \mathrm{m}$ ) and (B) germination of a phytopathogenic conidia.(C) Monosporic colonies of the Cylindrocarpontype anamorphs 2T-VSC-101 and 4I-VSC-314. (D) Inhibition of the mycelial growth of phytopathogen Ilyonectria liriodendri isolated monosporic 2T-VSC-101 in relation to the development of PGPB POA 75 and POA 89 in the study on in vitro antagonism. 

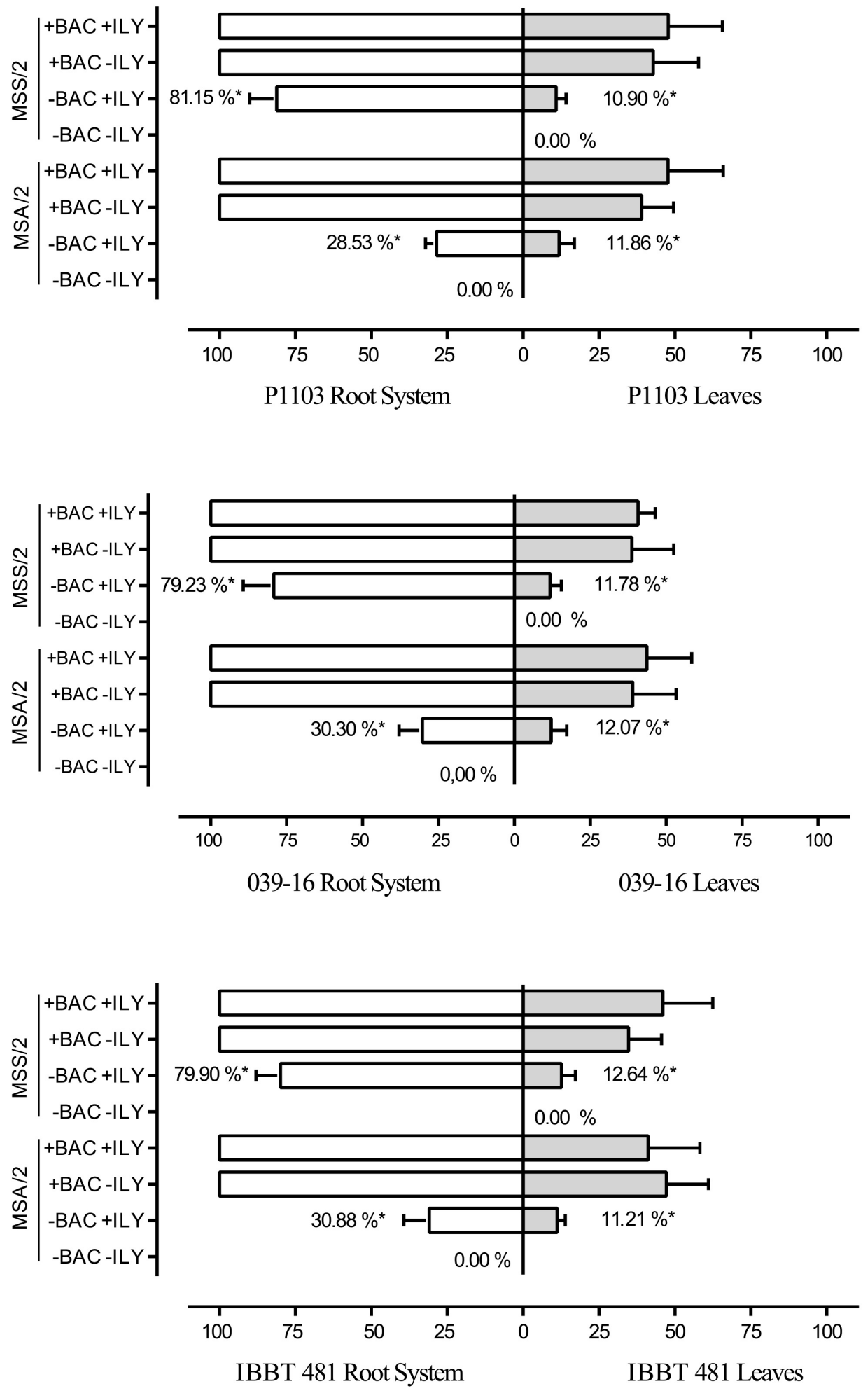

Figure 2- Foliar and root system damages (\%) of grapevine rootstocks P1103, VR039-16 and IBBT481 micropropagated in MS media, with half the salt concentration and solidified with agar (MSA/2) or pebbles (MSS/2), resulting from the interaction of the growth bacterium Burkholderia catarinensis sp. nov. isolated POA 89 (BAC) and the pathogenic fungus Ilyonectria liriodendri isolated monosporic 2T-VSC-101 (ILY), at 30 days after inoculation in vitro of the microorganisms $(\mathrm{n}=10)$. 


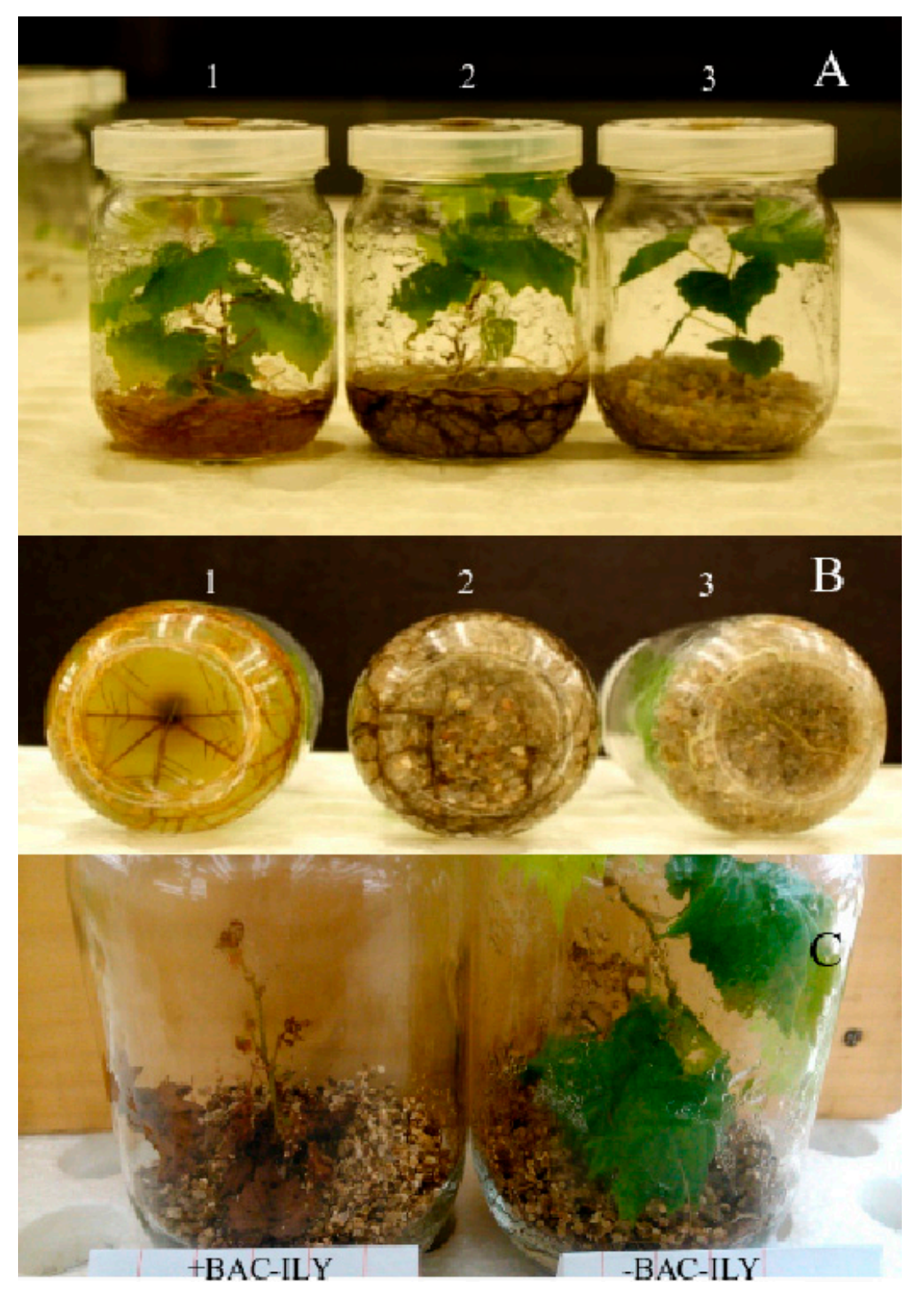

Figure 3 - (A, B) In vitro pathogenicity tests between grapevine rootstocks and the pathogenic fungus Ilyonectria liriodendri (ILY), isolated monosporic 2T-VSC-101. (A1, B1) P1103 in MSA/2 growth medium with + ILY; (A2, B2) P1103 in growth medium MSS/2 with + ILY and (A3, B3) in MSS/2 growth medium without -ILY. (C) Rootstock VR039-16 in growth medium MSS/2 in growth of bacteria POA 89 without the phythopathogen (+ BAC-ILY) (left) and without bacteria, without phytopathogen (-BAC-ILY) (right). 
Table 1 - Isolates of plant growth-promoting bacteria antagonists to the pathogenic fungus Ilyonectria liriodendri, isolated monosporic 2T-VSC-101.

\begin{tabular}{|c|c|c|c|c|c|c|c|c|}
\hline & & entification & & & Bact & erium $\mathbf{F}$ & POA & 89 / ILY \\
\hline PGPB & $\begin{array}{l}\text { Siderophore } \\
\quad(\mathbf{m m})\end{array}$ & $\begin{array}{c}\text { Phosphate } \\
\text { (mm) }\end{array}$ & $\begin{array}{c}\text { AIA } \\
u \text { g. } . \mathrm{mL}^{-1}\end{array}$ & Source & $\begin{array}{l}\mathrm{MR}^{(2)} \\
(\mathrm{cm})\end{array}$ & $\begin{array}{r}\text { RI } \\
\text { (\%) }\end{array}$ & & $\begin{array}{l}\text { Control } \\
(-) /(+)\end{array}$ \\
\hline Control & -------- & -------- & -------- & -------- & 6.02 & 0 & $\mathrm{a}$ & ------- \\
\hline POA 9. Rohnella sp. & 11.33 & 0 & 77.48 & Organic fruit farm soil & 5.58 & 7.31 & $\mathrm{a}$ & (-) absent \\
\hline POA 75. Burkholderia sp. & 15.67 & 0 & 7.23 & Native pasture soil & 4.22 & 29.90 & $\mathrm{~b}$ & (+) being \\
\hline POA 89. Burkholderia sp. & 17.71 & 0 & 15.56 & Native pasture soil & 3.45 & 42.69 & $\mathrm{c}$ & $(+)$ being \\
\hline POA 108. Pseudomonas sp. & 3.55 & 0 & 28.77 & Organic fruit farm soil & 6.02 & 0.33 & $\mathrm{a}$ & $(-)$ absent \\
\hline POA 187. Burkholderia sp. & 30.48 & 0 & 6.46 & Convencional fruit fram soil & 5.87 & 2.49 & $\mathrm{a}$ & $(-)$ absent \\
\hline POA 208. Burkholderia sp. & 24.66 & 4.19 & 10.39 & Convencional fruit fram soil & 5.70 & 5.32 & $\mathrm{a}$ & $(-)$ absent \\
\hline POA 195. Burkholderia sp. & 15.32 & 4.63 & 7.17 & Convencional fruit fram soil & 5.95 & 1.16 & $\mathrm{a}$ & $(-)$ absent \\
\hline POA 209. Leclercia sp. & 3.15 & 0 & 22.54 & Convencional fruit fram soil & 6.02 & 0.33 & $\mathrm{a}$ & $(-)$ absent \\
\hline POA 210. Leclercia sp. & 0 & 0 & 23.70 & Convencional fruit fram soil & 6.02 & 0.33 & $\mathrm{a}$ & $(-)$ absent \\
\hline POA 242. Ewingela sp. & 3.70 & 0 & 8.69 & Convencional fruit fram soil & 5.85 & 2.82 & $\mathrm{a}$ & $(-)$ absent \\
\hline POA 245. Burkholderia sp. & 2.27 & 0 & 9.68 & Convencional fruit fram soil & 4.08 & 32.23 & $\mathrm{~b}$ & (+) being \\
\hline POA 253. Burkholderia sp. & 16.98 & 0 & 6.46 & Convencional fruit fram soil & 5.72 & 4.98 & $\mathrm{a}$ & $(-)$ absent \\
\hline $\mathbf{p}$ & & & & & & & 000 & \\
\hline $\mathbf{F}$ & & - & --- & ---------------------- & & 35.25 & $514^{*}$ & \\
\hline CV(\%) & & & & & & & .72 & \\
\hline
\end{tabular}

(1) Analyzes issued by the Agricultural Research and Rural Extension Company of Santa Catarina (EPAGRI) from Lages, 2016. ${ }^{(2)}$ Different letters show significant differences according to the Tukey test $(\mathrm{p} \leq 0.005)$ for each of the analyzed variables. Relative inhibition, where: RI $(\%)=((\mathrm{AR}-\mathrm{MR}) / \mathrm{AR}) \times 100$, being: $\mathrm{AR}=$ average radius of the pathogen colony in the control treatment; $\mathrm{MR}=$ mean radius of the pathogen colony paired with the endophytic isolate.

Table 2 - Vegetative growth of the IBBT481 micropropagated grapevine rootstock, due to the interaction of the bacterium Burkholderia catarinensis sp. nov. isolated POA 89 (BAC) and the pathogenic fungus Ilyonectria liriodendri isolated monosporic 2T-VSC-101 (ILY), at 90 days after inoculation and acclimatization ( $\mathrm{n}=10)$.

\begin{tabular}{|c|c|c|c|c|}
\hline \multirow{2}{*}{$\begin{array}{l}\text { Variable/ } \\
\text { Treatment }\end{array}$} & \multicolumn{2}{|c|}{ Height $(\mathrm{cm})^{(1)}$} & \multicolumn{2}{|c|}{ Total dry biomass (g) } \\
\hline & - ILY & + ILY & - ILY & + ILY \\
\hline - BAC & 6.43 a A & $5.55 \mathrm{~A}^{\mathrm{b}}$ & 0.09 a A & $0.08 \quad \mathrm{~b} \mathrm{~A}$ \\
\hline$+\mathrm{BAC}$ & $5.61 \mathrm{a} \mathrm{B}$ & $6.67 \mathrm{a} \mathrm{A}$ & 0.11 a A & 0.13 a $\mathrm{A}$ \\
\hline Mean & \multicolumn{2}{|c|}{6.07} & \multicolumn{2}{|c|}{0.10} \\
\hline $\mathrm{p}$ & \multicolumn{2}{|c|}{0.0071} & \multicolumn{2}{|c|}{0.0267} \\
\hline CV (\%) & \multicolumn{2}{|c|}{17.17} & \multicolumn{2}{|c|}{26.37} \\
\hline
\end{tabular}

(1) Main stem height (cm), total dry biomass ( $\mathrm{g}$ ). Means followed by the same lowercase letter in the column and upper case in the row do not differ according to Tukey test $(\mathrm{p} \leq 0.005)$ for each of the analyzed variables. 


\section{Conclusions}

The isolates of bacteria POA 89, POA 108 and POA 245 of the gender Burkholderia sp. are promising as biological control agents of phytopathogen Ilyonectria liriodendri isolated monosporic 2T-VSC-101.

Burkholderia catarinensis sp. nov. isolated POA 89 , an antagonistic action in vitro to the agent causing the black foot of the vine, is harmful to plants under these conditions.

The cultivation in modified medium with sand (MSS/2) is suitable for the in vitro growth of the grapevine rootstocks P1103, IBBT481 and VR039-16 and it is appropriate for the observation of the characteristic symptoms of the black foot disease.

There are difficulties of acclimatization and ex vitro development of the IBBT481 rootstock, but there is greater growth of the plants when inoculated with the bacterium Burkholderia catarinensis sp. nov. isolated POA 89 in combination with phytopathogen Ilyonectria liriodendri isolated monosporic 2T-VSC-101.

\section{Acknowledgements}

To the Agricultural Research and Rural Extension Company of Santa Catarina (EPAGRI) of the municipalities of Videira, Caçador and, especially, of Lages, for the support granted to carry out the studies. To the Federal Institute of Science and Technology of Santa Catarina (IFC) and to the Coordination of Improvement of Higher-Level Personnel (CAPES) for the resources that made the project viable.

\section{References}

ADESEMOYE, A.O.; KLOEPPER, J.W. Plant-microbes interactions in enhanced fertilizer-use efficiency. Applied Microbiology and Biotechnology, New York, v.85, p.1-12. 2009.

AGUSTÍ-BRISACH, C.; ARMENGOL, J. Review: Black-foot disease of grapevine: an update on taxonomy, epidemiology and management strategies. Phytopathologia Mediterranea, Bologna, v.52, n.2, p.245-261, 2013.

AGUSTÍ-BRISACH, C.; MOSTERTB, L.; ARMENGOLA, J. Detection and quantification of Ilyonectria spp. associated with black-foot disease of grapevine in nursery soils using multiplex nested PCR and quantitative PCR. Plant Pathology, Oxford, v.63, p.316-322, 2014.
AHMAD, Ã.; AHMAD, I.; KHAN, M.S. Screening of free-living rhizospheric bacteria for their multiple plant growth promoting activities. Microbiological Research, Jena, v.163, p.173-181, 2008.

ALANIZ, S.; ABAD-CAMPOS, P.; GARCÍAJIMÉNEZ, J., ARMENGOL J. Evaluation of fungicides to control Cylindrocarpon liriodendri and Cylindrocarpon macrodidymum in vitro, and their effect during the rooting phase in the grapevine propagation process. Crop Protection, Guildford, v. 30, p. 489-494, 2011.

ALANIZ, S.; ARMENGOL, J.; LÉON, M.; GARCÍAJIMÉNEZ, J.; ABAD-CAMPOS, P. Analysis of genetic and virulence diversity of Cylindrocarpon liriodendri and C. macrodidymum associated with black foot disease of grapevine. Mycological Research, Cambridge, v.113, p.16-23, 2009.

ALANIZ, S.; LEÓN, M.; VICENT, A.; GARCÍAJIMÉNEZ, J.; ABAD-CAMPOS, P.; ARMENGOL, J. Characterization of Cylindrocarpon species associated with black foot disease of grapevine in Spain. Plant Disease, Saint Paul, v.91, n.9, p.1187-1193, 2007.

BACH, E.; SANT'ANNA, F.H.; PASSOS, J.F.M.; BALSANELLI, E.; BAURA, V.A.; PEDROSA F.O.; SOUZA, E.M.; PASSAGLIA, L.M.P. Detection of misidentifications of species from the Burkholderia cepacia complex and description of a new member, the soil bacterium Burkholderia catarinensis sp. nov. Pathogens and Disease, Amsterdam, v.75, n.6, p.1-8, 2017.

BAIS, H. P.; WEIR, T. L.; PERRY, L. G.; SIMON GILROY, S.; VIVANCO, J. M. The role of root exudates in rhizosphere interactions with plants and other organisms. Annual Review of Plant Biology, Palo Alto, v.57, p.233-266, 2006.

BERG, G.; SMALLA, K. Plant species and soil type cooperatively shape the structure and function of microbial communities in the rhizosphere. Federation of European Microbiological Societies, Oxford, v. 68, p. 1-13, 2009.

BETTONI, J. C.; DALLA COSTA, M.; GARDIN, J. P. P. KRETZCHMAR, A. A.; SOUZA, J. A. In vitro propagation of grapevine cultivars with potential for south of Brazil. American Journal of Plant Sciences, Dübendorf, v.6, p.1806-1815, 2015.

BRAYFORD, D. Cylindrocapon obtusisporum. Mycopathologia, Den Haag, v. 100, p. 129-130, 1987. 
BRAYFORD, D. Cylindrocarpon. In: SINGLETON, L.L.; MIHAIL, J.D.; RUSH, C.M. (ed.). Methods for research soilborne phytopatohogenic fungi. Michigan: American Phytopathological Societ Press, 1993. p.103106.

CABRAL, A.; REGO, C.; CROUS, P. W.; OLIVEIRA, $\mathrm{H}$. Virulence and cross-infection potential of llyonectria spp. to grapevine. Phytopathologia Mediterranea, Bologna, v.51, n.2, p.340-354, 2012 a.

CABRAL, A.; REGO, C.; NASCIMENTO, T.; OLIVEIRA, H.; GROENEWALD, J. Z.; CROUS, P. W. Multi-gene analysis and morphology reveal novel Ilyonectria species associated with black foot disease of grapevines. Fungal Biology, Amsterdam, v.116, p.6280,2012 b.

CHAVERRI P.; SALGADO, C.; HIROOKA, Y.; ROSSMAN, A. Y.; SAMUELS, G. J. Delimitation of Neonectria and Cylindrocarpon (Nectriaceae, Hypocreales, Ascomycota) related genera with Cylindrocarpon-like anamorphs. Studies in Mycology, Manchester, v.68, p.57-78, 2011.

COMPANT, S.; CLÉMENT, C.; SESSITSCH, A. Plant growth-promoting bacteria in the rhizo- and endosphere of plants: Their role, colonization, mechanisms involved and prospects for utilization. Soil Biology \& Biochemistry, Oxford, v.42, p.669-678, 2010.

FONTAINE, F.; GRAMAJE, D.; ARMENGOL, J.; SMART, R.; NAGY, Z. A.; BORGO, M.; REGO, C.; CORIO-COSTET, M. F. FUENTE, M. de la (coord.). Grapevine trunk diseases: a review. Paris: OIV publications, 2016. p.1-24.

GAIERO, J.R.; MCCALL, C.A.; THOMPSON, K.A.; DAY, N.J.; BEST, A.S.; DUNFIELD, K.E. Inside the root microbiome: bacterial root endophytes and plant growth promotion. American Journal of Botany, Lancaster, v.100, n.9, p.1-13, 2013.

GARRIDO, L.G., SÔNEGO, O.R. \& URBEN, A.F. Cylindrocarpon destructans causador do "pé-preto" da videira no Rio Grande do Sul. Fitopatologia Brasileira, Brasília, DF, v.29, p.548-550, 2004.

GLICK, B. R. Review article: plant growth-promoting bacteria: mechanisms and applications. Scientifica, Paris, p.1-15, 2012.

GOSAL, S.K.; KARLUPIA, A.; GOSAL, S.S.; CHHIBBA, I.M.; VARMA, A. Biotization with Piriformospora indica and Pseudomonas flurescens improves survival rate, nutrient acquisition, field performance and saponin content of micropagated Chlorophytum sp. Indian Journal of Biotechnology, New Delhi, v.9, p.289-297, 2010.
GRIMALT, S.; DEHOUCK, P. Review of analytical methods for the determination of pesticide residues in grapes. Journal of Chromatography A, Amsterdam, n.1433, p.1-23, 2016.

HALLEEN, F.; FOURIE, P. H.; CROUS, P. W. A review of black foot disease of grape vine. Phytopathologia Mediterranea, Bologna, v. 45, p. 55-67, 2006.

KING, P.R.N.; KING, E.J. Estimation of plasma phosphatase by determination of hydrolysed phenol with amino-antipyrine. Journal of Clinical Pathology, London, v.7, p.322, 1954.

LAMICHHANE, J. R.; VENTURI, V. Synergisms between microbial pathogens in plant disease complexes: a growing trend. Frontiers in Plant Science, Lausanne, v.6, p.1-12, 2015.

LENNETTE, E.H.; BALOWS, A.; HAUSLER, W.J.; SHADOMY, H.J. Manual of clinical microbiology. Washington: American Society for Microbyology, 1985.

MARIANO, R.L.R.; SILVEIRA, E.B.; ASSIS, S.M.; GOMES, A.M.; NASCIMENTO, A.R.; DONATO, V.M.T.S. Importância de bactérias promotoras de crescimento e de biocontrole de doenças de plantas para uma agricultura sustentável. Anais Academia Pernambucana de Ciência Agronômica, Recife, v.1, p.89-111, 2004.

MOHAMMADI, H.; ALANIZ, S.; BANIHASHEMI, Z.; ARMENGOL, J. Characterization of Cylindrocarpon liriodendri associated with black foot disease of grapevine in Iran. Journal of Phytopathology, Recife, v. 157, p.642-645, 2009.

MONCADA, U.A.P.; GÓMEZ, M.M.R.; NARVÁEZ, Y.A.Z.; SÁNCHEZ, J.M.C. Effect of the single and combined inoculation with Arbuscular Mycorrhizal Fungi (AMF) and Plant Growth Promoting Rhizobacteria (PGPR) in micropropagated blackberry plants (Rubus glaucus L.). Corpoica Ciencia y Tecnología Agropecuaria, Bogotá, v.16, p.95-103, 2015.

MORAES, L. de.; SANTOS, R.K.; ZEIZER, T.W.; KRUPEK, R.A. Avaliação da área foliar a partir de medidas lineares simples de cinco espécies vegetais sob diferentes condições de luminosidade. Revista Brasileira de Biociências, Porto Alegre, v.11, n.4, p.381-387, 2013.

MURASHIGE, T.; SKOOG, F. A revised medium for rapid growth and bioassays with tobacco tissue cultures. Physiologia Plantarum, Copenhagen, v.15, p.473-479, 1962. 
NOWAK, J. Review: benefits of in vitro "biotization" of plant tissue cultures with microbial inoculants. In Vitro Cellular \& Developmental Biology - Plant, Cambridge, v.34, p.122-130, 1998.

ORLIKOWSKA, T.; NOWAK, K.; REED, B. Bacteria in the plant tissue culture environment. Plant Cell, Tissue and Organ Culture, Dordrecht, v.128, n.3, p.487-508, 2017.

OSBORNE, J.W. Improving your data transformations: Applying the Box-Cox transformation. Practical Assessment, Research \& Evaluation, Maryland, v.15, n.12, p.1-9, 2010.

PASSOS, J.F.M.; COSTA, P.B.; COSTA, M.D.; ZAFFARI, G.R.; NAVA, G.; BONETI, J.I.; OLIVEIRA, A.M.R.; PASSAGLIA, L.M.P. Cultivable bacteria isolated from apple trees cultivated under different crop systems: Diversity and antagonistic activity against Colletotrichum gloeosporioides. Genetics and Molecular Biology, Ribeirão Preto, v.37, n.3, p.1-13, 2014.

PATHROSE, B.; JONES, E.E.; JASPERS, M.V.; RIDGWAY, H.J. High genotypic and virulence diversity in Ilyonectria liriodendri isolates associated with black foot disease in New Zealand vineyards. Plant Pathology, Oxford, v.63, p.613-624, 2014.

PETIT, E.; BARRIAULT, E.; BAUMGARTNER, K.; WILCOX, W. F.; ROLSHAUSEN, P. E. Cylindrocarpon species associated with black-foot of grapevine in northeastern United States and southeastern Canada. American Journal of Enology and Viticulture, Davis, v.62, n.2, p.177-183, 2011.

RANA, A.; SAHGAL, M.; JOHRI, B.N. Fusarium oxysporum: genomics, diversity and plant-host interaction. In: SATYANARAYANA, T.; DESHMUKH, S.; JOHRI, B.N. (ed.). Developments in fungal biology and applied mycology. Singapoure: Springer, 2017. p.159-199.

REGO, C.; OLIVEIRA, H.; CARVALHO, A.; PHILLIPS, A. Involvement of Phaeoacremonium spp. and Cylindrocarpon destructans with grapevine decline in Portugal. Phytopathologia Mediterranea, Bologna, v.39, p. 76-79, 2000.

REINHART, V. Multiplicação de matrizes de portaenxertos híbridos de videira (Vitis labrusca $x$ Vitis rotundifolia) por micropropagação. 2013. Dissertação (Mestrado em Ciências) - Universidade Federal do Paraná, Curitiba, 2013.
RESH, H. M. Cultivos hidropônicos: nuevas técnicas de producción. 4.ed. Madrid: Mundi-Prensa, 1997. 378 p.

RUSSI, A.; NALIN, R.; DEQUIGIOVANNI, G.; GAVA, R.; QUECINI, V.; GARRIDO, L.R. and RITSCHEL, P. Study of the genetic variability of Brazilian populations of Cylindrocarpon spp., causal agent of grapevine black foot. Phytopathologia Mediterranea, Bologna, v.49, p.111-112, 2010.

SAMUELS, G.J.; BRAYFORD, D. Variation in Nectria radicicola and its anamorph, Cylindrocarpon destructans. Mycological Research, Cambridge, v.94, p.433-442, 1990.

SANTOYO, G.; MORENO-HAGELSIEB G.; OROZCO-MOSQUEDA, M. C.; GLICK, B. R. Review Plant growth-promoting bacterial endophytes. Microbiological Research, Amsterdam, v. 183, p. 9299, 2016.

SENGUPTA, A.; GUNRI, S. K. Microbial intervention in agriculture: An overview. African Journal of Microbiology Research, Lagos, v. 9, n. 18, p. 12151226, 2015.

SHIOMI, D.; SAKAI, M.; NIKI, H. Determination of bacterial rod shape by a novel cytoskeletal membrane protein. The EMBO Journal, Oxford, v.27, n.23, p.3081-3091, 2008.

SILVA, F.A.S; AZEVEDO, C.A.V. The assistat software version 7.7 and its use in the analysis of experimental data. African Journal of Agricultural Research, Nairobi, v.11, n.39, p.3733-3740, 2016.

STALEY, Z.R.; ROHR, J.R.; SENKBEIL, J.K.; HARWOOD, V.J. Agrochemicals indirectly increase survival of E. coli 0157:H7 and indicator bacteria by reducing ecosystem services. Ecological Applications, Washington, v.24, n.8, p.1945-1953, 2014.

SUN, Z.B.; ZHANG, J.; SUN, M.H.; LI, S.D. Identification of genes related to chlamydospore formation in Clonostachys rosea 67-1. Microbiology Open, Oxford, v.8, p.1-11, 2019.

THOMMA, B.P.H.J. Pathogen profile Alternaria spp.: from general saprophyte to specific parasite. Molecular Plant Pathology, Oxford, v.4, n.4, p.225-236, 2003. 